\title{
Guest Editorial to the Symposium on European Union Governance of Health Crisis and Disaster Management: Key Norms and Values, Concepts and Techniques
}

\author{
Mark L FLEAR(D and Anniek DE RUIJTER*
}

\section{INTRODUCTION}

The genesis of this symposium lay in a simple observation: there is a fast developing and growing infrastructure for health crisis and disaster management at the European level of governance. ${ }^{1}$ This infrastructure is formed by a number of key organisations, especially the European Union (EU), which often works with the World Health Organisation (that is, WHO Europe), and to a lesser extent the Council of Europe. Since the early 2000s, the European level has been increasingly involved in most - if not all - of the key health crises and disasters threatening to impact within Europe. Preparedness planning for terrorist attacks and pandemics provides perhaps the most obvious and recurrent example. There is also the ongoing migration crisis, affecting the southern fringes of Europe in particular. Volcanic eruptions have grounded air travel for fear of lost lives from planes falling from the sky. And further back, in the 1990s, BSE/CJD ${ }^{2}$ led to fears of an impact on human health as a result of farming techniques for cows.

\footnotetext{
Respectively, School of Law, Queen's University Belfast; email: m.flear@qub.ac.uk, and Amsterdam Law School, University of Amsterdam and Amsterdam Centre for European Law and Governance; email: A.deRuijter@uva.nl. Many thanks to all those with whom we have discussed the ideas set out in this article - and a massive thank you to our contributors. We acknowledge funding from the Netherlands Organsisation for Scientific Research (NWO-veni) and administrative support by Desiree Blessing and Kaan Ozdurak.

1 MBA van Asselt et al, "Some Reflections on EU Governance of Critical Infrastructure Risks" (2015) 6(2) EJRR 185; L Bengtsson and M Rhinard, "Securitisation across Borders: The Case of 'Health Security' Cooperation in the European Union" (2019) 42(2) West European Politics 346; H Dijkstra and A de Ruijter, "The Health-Security Nexus and the European Union: Toward a Research Agenda" (2017) 8(4) EJRR 1; ML Flear, Governing Public Health: EU Law, Regulation and Biopolitics (Hart Publishing 2015 hb; 2018 (revised) pb), especially ch 4 "HIV/AIDS", ch 5 "Pandemics and Beyond" and ch 6 for discussion on the centrality of risk (pp 170-174) and the underpinnings of the EU's public health policy domain (pp 174-177); ML Flear, “'Technologies of Reflexivity': Generating Biopolitics and Institutional Risk to Supplement Global Public Health Security" (2017) 8(4) EJRR 658; M Frischhut and S Greer, "EU Public Health Law and Policy - Communicable Diseases" in TK Hervey et al (eds), Research Handbook on EU Health Law and Policy (Edward Elgar 2017); TK Hervey, "The Role of the European Court of Justice in the Europeanisation of Communicable Disease Control: Driver or Irrelevance?" (2012) 37(6) Journal of Health Politics, Policy and Law 977; TK Hervey, "The EU's (Emergent) Global Health Law and Policy" in Hervey et al, ibid; A de Ruijter, "Mixing EU Security and Public Health in the Health Threats Decision" in A de Ruijter and M Weimer (eds), EU Risk Regulation, Expert and Executive Power (Hart Publishing 2017); A de Ruijter, EU Health Law \& Policy: The Expansion of EU Power in Public Health and Health Care (Oxford University Press 2019).

2 Variant Creutzfeldt-Jakob disease, which is said to develop from the transmission of bovine spongiform encephalopathy (BSE) from infected animal products to humans.
} 
The role of the European level, and the EU in particular, is becoming increasingly apparent, and is almost part of the everyday.

The crisis and disaster management literature is widening understanding of this area. Nevertheless, there is still surprisingly little focus on the European space for governance. ${ }^{3}$ Much of the attention appears to remain on the WHO - the EU seldom enters the frame for discussion. Nevertheless, and by contrast, within EU legal scholarship there is a growing appreciation of the importance of EU law and governance to health crisis and disaster management. ${ }^{4}$ This is not surprising, given EU governance in this, and indeed other areas, is usually predicated on law. ${ }^{5}$ This symposium is the first of its kind and is the product of an event held at the University of Amsterdam on 6 and 7 December 2018. The symposium examines EU governance of health crisis and disaster management, and identifies and reflects on some of its constitutive elements of governance: its key norms and values, concepts, and techniques for implementation.

By looking at these elements of governance, the aim of the symposium as a whole is to begin to answer a number of key questions: Is there a distinctive character to EU governance of health crisis and disaster management? What challenges do responses to health crises and disasters pose for EU fundamental principles of law, in particular the rule of law, and how does this impact on the constitutional order? What are the epistemic foundations for EU governance, both at the EU level and as EU-level norms and instruments are implemented at Member State level? How has EU governance been enabled by technological developments in the area of data gathering, interpretation and use?

\section{HeAlth EMERGENCIES AND FUndAmENTAL PRINCIPLES OF LAW}

The first group of papers examines the key norms, values and concepts of EU health crisis governance. Brito Bastos and de Ruijter reflect on the ways in which health emergencies privilege executive power, and consider to what extent current EU principles of law can maintain the balance of power in an emergency. In so doing, the authors add to extant discussion on health emergencies and the rule of law. ${ }^{6}$ A response to an emergency can sometimes lead to the creation of exceptions to rule of law guarantees that bind authorities to procedural rules and fundamental rights. When these changes become permanent, they may break or bend the constitutionally-derived rules applicable to health emergencies, with implications for the rule of law.

3 B Dillon et al, Blackstone's Emergency Planning, Crisis, and Disaster Management, $2^{\text {nd }}$ edn (Oxford University Press 2014); BM Hutter and S Lloyd-Bostock, Regulatory Crisis: Negotiating the Consequences of Risk, Disasters and Crises (Cambridge University Press 2017); N Kapucu and A Boin, Disaster and Crisis Management: Public Management Perspectives (Routledge 2015).

4 See references in note 1 above.

5 See, seminally, JHH Weiler, "The Transformation of Europe" (1991) 100 The Yale Law Journal 2403; A Vauchez, "The Transnational Politics of Judicialisation. Van Gend En Loos and the Making of EU Polity" (2009) 16 European Law Journal 1

6 For instance: DP Fidler and LO Gostin, Biosecurity in the Global Age: Biological Weapons, Public Health, and the Rule of Law (Stanford University Press 2007); G Harlem Brundtland, "Global Health and International Security" (2003) 9(4) Global Governance 417; D Heymann, "Evolving Infectious Disease Threats to National and Global Security" in L Chen et al (eds), Global Health Challenges for Human Security (Harvard University Press 2003); S Hinchcliffe and N Bingham, "Securing Life: the emerging practices of biosecurity" (2008) 40(7) Environment and Planning A 1534; G Prins, "AIDS and Global Security" (2004) 80(5) International Affairs 931. 
The impact of health emergencies can also be seen in the right to informed consent. This is a key expression of individual autonomy, but may be overridden in the interests of safeguarding public health and security in emergency situations. The implications of the EU's health emergency frameworks for informed consent are discussed by Van Kolfschooten. Member State law and policies on health emergencies are substantially shaped by EU and international actions, with implications for the protection of the right to informed consent. Specifically, EU frameworks are found wanting in this regard. As such, it is argued that the EU should better integrate human rights considerations in its frameworks, even in the context of soft rules and coordination.

EU legal frameworks are implicated in health research regulation at the Member State level, and these provide further examples of health crises and disasters, as Flear examines. Flear offers further reflection on harm as the utilitarian basis for interventions in the public domain. In his account, gaps and blindspots in knowledge arise from the framing of health research regulation, and may produce epistemic injustice (harm to individuals in their capacity as knowers). Resolving epistemic injustice becomes important, not only because it is a harm in itself, but because it may underlie other harms, including to research participants and their adjuncts, such as personal data. Flear's contribution sketches a way forward towards the resolution of epistemic injustice, in order to better anticipate and prevent future health crises and disasters, and protect health and individual rights.

\section{KNOWLEDGE IN THE CONSTRUCTION OF EU GOVERnANCE}

A further group of papers examine the techniques of health crisis and disaster management to draw attention to the foundational role of knowledge and information in the construction of EU governance. Action to tackle health crises and disasters can become self-perpetuating. There must be attention to the harm itself, but also to the inadvertent effects of governance. Knowledge on health crises and disasters helps to define a problem and the space for governance. It is within this space that legal principles, the protection of health and individual rights shape public health interventions. New knowledge-based practices also widen opportunities for governance, and thus present challenges to law in shaping future interventions.

For instance, Roberts describes how the techniques of new digital surveillance practices for European health security play an increasingly foundational role for governance, especially in the context of heightened pandemic vigilance. The rise of digital technologies and data have enabled EU health security agents to improve and widen infectious disease surveillance to the point that new practices have emerged. These blend together digitised alerts with long-established and pre-existing disease surveillance legacies of EU Member States. Epistemic and methodological shifts in the production of knowledge underpin governance practices through alerts and signals for accelerated infectious disease surveillance.

The central role of knowledge for the functioning of EU governance of health crises and disasters is also discussed by Dąbrowska-Kłosińska. The techniques used in the exchange of information present both a source and driver of regulatory activities. In this regard, Decision 1082/2013 was adopted with the aim of providing the basis for 
preparedness and response mechanisms for serious cross-border health threats (including diseases, bioterrorist, chemical or environmental events). ${ }^{7}$ This legal instrument strongly relies on the electronic exchange of information via various digital tools and platforms. The article shines new light on the distinctive features of these mechanisms and the possible obstacles to their operation.

\section{IMAGINING "EuROPE"}

One of the key understandings that arose in the context of describing the key values, concepts and techniques of EU health crisis management, was that this policy area provides a lens through we can see how the EU imagines itself, and projects its identity to its citizens, and the world at large. It has long been recognised that law and governance are integral to imaginaries or ways of imagining and thinking about "Europe" and its identity. ${ }^{8}$ Yet, up until now wider legal and regulatory studies scholarship has rarely reflected on the significance of imaginaries for law, regulation and governance. The concept of imaginaries derives from social science and has been developed within science and technology studies and anthropology. As McNeil and colleagues argue, the concept "seems to offer new ways to investigate the relationships among science, technology, and society". 9 These relationships are also present in EU governance of health crisis and disaster management, where in science and technology play significant foundational roles, as we have just noted.

The concept of imaginaries adds to our understanding of the importance of health crisis and disaster management governance to the EU's identity and legitimation. Brito Bastos and de Ruijter underscore the extent to which law and the rule of law remain of fundamental importance to the EU's imaginary and the legitimation of EU governance. Flear identifies imaginaries as significant features of regulatory framings of health research regulation, which are underpinned by EU law, and threatened by health scandals and crises.

The importance of imaginaries is also acutely apparent in EU migration management, discussed by Dickson. The understanding of the management of migration within EU discourses, and especially migration coming through the southern Member States from Africa and the Middle East, may be seen as connected to the EU's own "health". Dickson argues that a language of health imbues migration management at the EU level, and affects the legal position of the migrant as a person with(out) rights. More deeply, at the root of this problem lies a chronic lack of solidarity between Member States for cooperation and integration in migration policy. The latter fractures the imaginary of the EU as an organisation where there is sincere cooperation by its Member States in the construction and implementation of common EU rules and policies. ${ }^{10}$ Dickson thus offers novel insight into the shallowness of the

7 Decision 1082/2013/EU on serious cross-border threats to health and repealing Decision 2119/98/EC OJ L 293/1.

8 Flear, supra, note 1; Weiler, supra, note 5.

9 MC McNeil et al, "Conceptualising Imaginaries of Science, Technology and Society" in K Konrad et al, The Handbook of Science and Technology Studies, $4^{\text {th }}$ edn (MIT Press 2017).

10 Art 4(3) Treaty on European Union. 
EU's imaginary, in relation to solidarity, and points to this as an explanation for the EU's failure to deal with the entrenched health crisis and disaster on its own borders.

There is a clear resonance here with Flear's call to look at the roots of harms to health within framing and the organisation of knowledge for governance and regulation. Together the articles in the symposium provide new insights into how health crisis and disaster management helps to constitute and legitimate "the" EU.

\section{IS THERE A DISTINCTIVE CHARACTER TO EU GOVERNANCE OF HEALTH CRISIS AND DISASTER MANAGEMENT?}

Our answer to the lead question for this symposium is a tentative "yes". There is clearly much more to do to fully map and deepen understanding of this new area, and to contribute constructively to the development of EU governance in health security. The symposium provides partial answers to the questions that prompted the initial event where the articles here were first presented. Nevertheless, there are emerging signs that EU governance of health crisis and disaster management is distinctive in the specific values and concepts that underlie its development, and due to the particular policy context and approaches to knowledge that are promulgated in EU governance processes.

The free circulation of people and things throughout, and into, the EU's internal market, in some circumstances (such as migration) overlaid by the area of freedom, security and justice and civil protection, remains the core around which health crisis and disaster management governance is being built. Risk also plays a central role, both in terms of co-constituting "health crises", "health disasters" or "health emergencies" with the relevant (exchanges of) knowledge, and mediating responsibilities and accountabilities between the multiple levels of EU governance. This growing and developing governance is one where law, including the rule of law, and fundamental and human rights, structure relationships between the different levels of governance, and between governances and their citizens, or third-country nationals.

Difficulties in abiding by legal norms and principles in the context of emergencies, and the legal leeway in this respect, may give rise to questions, and where necessary public and potentially legal accountability. Holding to account through law is a key feature of liberal democracy, and the potential to do so in this area further underscores how EU governance, while remaining problematic in several regards, can be discussed and potentially shaped through public demands and questions.

New ways of creating and using knowledge are powerful influences in the current shape and future direction of EU governance, the way in which "the" EU is thought about, its narrative about itself, and identity. The multi-faceted importance of EU governance in the area of health crisis and disaster management, and the areas of concern discussed in several of the following articles, raises questions about the sufficiency of EU governance fora and structures to provide the necessary coherence, oversight and protection for EU citizens and non-citizens alike. Read together, the contributions to the symposium announce a new area of governance and site for much further scholarly debate and public attention. 